This article was downloaded by: [58.96.53.117]

On: 12 February 2014, At: 14:45

Publisher: Taylor \& Francis

Informa Ltd Registered in England and Wales Registered Number: 1072954 Registered

office: Mortimer House, 37-41 Mortimer Street, London W1T 3J H, UK

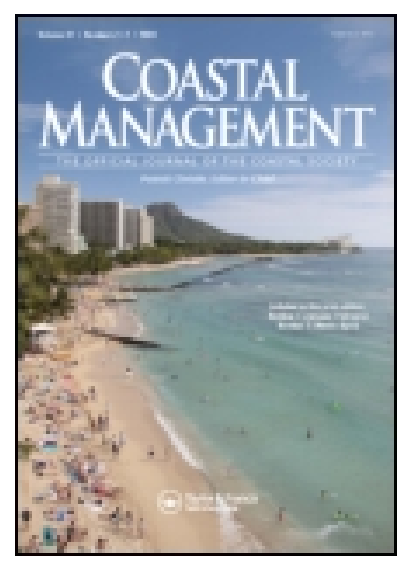

Coastal Management

Publication details, including instructions for authors and subscription information:

http:// www. tandfonline.com/loi/ ucmg20

\title{
Developing Marine Protected Area Networks in the Coral Triangle: Good Practices for Expanding the Coral Triangle Marine Protected Area System
}

Rebecca Weeks $^{a}$, Porfirio M. Aliño ${ }^{b}$, Scott Atkinson ${ }^{c}$, Pacifico Beldia II ${ }^{d}$ e , Augustine Binson ${ }^{f}$, Wilfredo L. Campos ${ }^{g}$, Rili Djohani ${ }^{h}$, Alison L. Green ${ }^{i}$, Richard Hamilton ${ }^{j}$, Vera Horigue ${ }^{a}$ b, Robecca

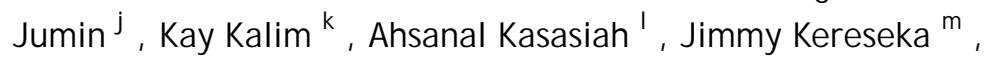
Carissa Klein $^{n}$, Lynette Laroya ${ }^{\circ}$, Sikula Magupin ${ }^{j}$, Barbara Masike $p$, Candice Mohan ${ }^{q}$, Rui Miguel Da Silva Pinto ${ }^{r}$, Agnetha VaveKaramui ${ }^{\mathrm{s}}$, Cesar Villanoy ${ }^{\mathrm{b}}$, Marthen Welly ${ }^{\mathrm{h}} \&$ Alan T. White ${ }^{\mathrm{t}}$ ${ }^{a}$ ARC Centre of Excellence for Coral Reef Studies, J ames Cook University, Townsville, Queensland, Australia

${ }^{b}$ The Marine Science Institute, University of the Philippines, Diliman, Quezon City, Philippines

${ }^{c}$ Conservation International

${ }^{d}$ Conservation International Philippines, Diliman, Quezon City , Philippines

e Malampaya Foundation, Inc.

f Sabah Parks, Kota Kinabalu, Sabah, Malaysia

${ }^{g}$ Division of Biological Sciences, College of Arts and Sciences, University of the Philippines Visayas, Iloilo , Philippines

${ }^{\mathrm{h}}$ Coral Triangle Center, Sanur, Bali , Indonesia

'The Nature Conservancy, Brisbane, Queensland, Australia

${ }^{j}$ WWF Malaysia, Kota Kinabalu, Sabah, Malaysia

${ }^{k}$ Department of Environment and Conservation, Port Moresby , Papua New Guinea

I Ministry of Marine Affairs and Fisheries, Jakarta, Indonesia

$\mathrm{m}$ The Nature Conservancy, Honiara, Solomon Islands

${ }^{n}$ ARC Centre of Excellence for Environmental Decisions, University of Queensland, St. Lucia, Queensland, Australia

${ }^{\circ}$ Protected Areas and Wildlife Bureau, Department of Environment and Natural Resources, Diliman, Quezon City, Philippines

${ }^{p}$ The Nature Conservancy, Port Moresby, Papua New Guinea

${ }^{q}$ Conservation International Timor-Leste, Dili, Timor-Leste 
${ }^{r}$ Rai Consultadoria, Dili , Timor-Leste

${ }^{\mathrm{s}}$ Ministry of Environment, Climate Change, Disaster Management \& Meteorology, Honiara, Solomon Islands

t The Nature Conservancy, Honolulu, Hawaii , USA

Published online: 12 Feb 2014.

To cite this article: Rebecca Weeks, Porfirio M. Aliño, Scott Atkinson, Pacifico Beldia II , Augustine Binson, Wilfredo L. Campos, Rili Djohani , Alison L. Green, Richard Hamilton, Vera Horigue, Robecca J umin , Kay Kalim, Ahsanal Kasasiah, J immy Kereseka, Carissa Klein , Lynette Laroya, Sikula Magupin, Barbara Masike, Candice Mohan, Rui Miguel Da Silva Pinto, Agnetha Vave-Karamui , Cesar Villanoy, Marthen Welly \& Alan T. White (2014) Developing Marine Protected Area Networks in the Coral Triangle: Good Practices for Expanding the Coral Triangle Marine Protected Area System, Coastal Management, 42:2, 183-205, DOI: 10.1080/08920753.2014.877768

To link to this article: http:// dx.doi.org/ 10.1080/08920753.2014.877768

\section{PLEASE SCROLL DOWN FOR ARTICLE}

Taylor \& Francis makes every effort to ensure the accuracy of all the information (the "Content") contained in the publications on our platform. Taylor \& Francis, our agents, and our licensors make no representations or warranties whatsoever as to the accuracy, completeness, or suitability for any purpose of the Content. Versions of published Taylor \& Francis and Routledge Open articles and Taylor \& Francis and Routledge Open Select articles posted to institutional or subject repositories or any other third-party website are without warranty from Taylor \& Francis of any kind, either expressed or implied, including, but not limited to, warranties of merchantability, fitness for a particular purpose, or noninfringement. Any opinions and views expressed in this article are the opinions and views of the authors, and are not the views of or endorsed by Taylor \& Francis. The accuracy of the Content should not be relied upon and should be independently verified with primary sources of information. Taylor \& Francis shall not be liable for any losses, actions, claims, proceedings, demands, costs, expenses, damages, and other liabilities whatsoever or howsoever caused arising directly or indirectly in connection with, in relation to or arising out of the use of the Content.

This article may be used for research, teaching, and private study purposes. Any substantial or systematic reproduction, redistribution, reselling, loan, sub-licensing, systematic supply, or distribution in any form to anyone is expressly forbidden. Terms \& Conditions of access and use can be found at http://www.tandfonline.com/page/termsand-conditions

Taylor \& Francis and Routledge Open articles are normally published under a Creative Commons Attribution License http://creativecommons.org/licenses/by/3.0/. However, authors may opt to publish under a Creative Commons Attribution-Non-Commercial License http://creativecommons.org/licenses/by-nc/3.0/ Taylor \& Francis and Routledge Open Select articles are currently published under a license to publish, which is based upon the Creative Commons Attribution-Non-Commercial No-Derivatives License, but allows for text and data mining of work. Authors also have the option of publishing an Open Select article under the Creative Commons Attribution License http:// creativecommons.org/licenses/by/3.0/.

It is essential that you check the license status of any given Open and Open Select article to confirm conditions of access and use. 


\title{
Developing Marine Protected Area Networks in the Coral Triangle: Good Practices for Expanding the Coral Triangle Marine Protected Area System
}

\author{
REBECCA WEEKS, ${ }^{1}$ PORFIRIO M. ALIÑO, ${ }^{2}$ SCOTT \\ ATKINSON, ${ }^{3}$ PACIFICO BELDIA II, ${ }^{4,5}$ AUGUSTINE BINSON, ${ }^{6}$ \\ WILFREDO L. CAMPOS, ${ }^{7}$ RILI DJOHANI, ${ }^{8}$ ALISON L. \\ GREEN, ${ }^{9}$ RICHARD HAMILTON, ${ }^{10}$ VERA HORIGUE, ${ }^{1,2}$ \\ ROBECCA JUMIN, ${ }^{10}$ KAY KALIM, ${ }^{11}$ AHSANAL KASASIAH, ${ }^{12}$ \\ JIMMY KERESEKA, ${ }^{13}$ CARISSA KLEIN,${ }^{14}$ LYNETTE \\ LAROYA, ${ }^{15}$ SIKULA MAGUPIN,${ }^{10}$ BARBARA MASIKE,${ }^{16}$ \\ CANDICE MOHAN, ${ }^{17}$ RUI MIGUEL DA SILVA PINTO, ${ }^{18}$ \\ AGNETHA VAVE-KARAMUI, ${ }^{19}$ CESAR VILLANOY, ${ }^{2}$ \\ MARTHEN WELLY, ${ }^{8}$ AND ALAN T. WHITE ${ }^{20}$
${ }^{1}$ ARC Centre of Excellence for Coral Reef Studies, James Cook University, Townsville, Queensland, Australia
${ }^{2}$ The Marine Science Institute, University of the Philippines, Diliman, Quezon City, Philippines
${ }^{3}$ Conservation International
${ }^{4}$ Conservation International Philippines, Diliman, Quezon City, Philippines
${ }^{5}$ Malampaya Foundation, Inc.
${ }^{6}$ Sabah Parks, Kota Kinabalu, Sabah, Malaysia
${ }^{7}$ Division of Biological Sciences, College of Arts and Sciences, University of the Philippines Visayas, Iloilo, Philippines
${ }^{8}$ Coral Triangle Center, Sanur, Bali, Indonesia
${ }^{9}$ The Nature Conservancy, Brisbane, Queensland, Australia
${ }^{10}$ WWF Malaysia, Kota Kinabalu, Sabah, Malaysia
${ }^{12}$ Ministry of Marine Affairs and Fisheries, Jakarta, Indonesia
${ }^{13}$ The Nature Conservancy, Honiara, Solomon Islands
${ }^{14}$ ARC Centre of Excellence for Environmental Decisions, University of Queensland, St. Lucia, Queensland, Australia
${ }^{15}$ Protected Areas and Wildlife Bureau, Department of Environment and Natural Resources, Diliman, Quezon City, Philippines
${ }^{16}$ The Nature Conservancy, Port Moresby, Papua New Guinea \\ ${ }^{11}$ Department of Environment and Conservation, Port Moresby, Papua New Guinea
}

(C) Rebecca Weeks, Porfirio M. Aliño, Scott Atkinson, Pacifico Beldia Ii, Augustine Binson, Wilfredo L. Campos, Rili Djohani, Alison L. Green, Richard Hamilton, Vera Horigue, Robecca Jumin, Kay Kalim, Ahsanal Kasasiah, Jimmy Kereseka, Carissa Klein, Lynette Laroya, Sikula Magupin, Barbara Masike, Candice Mohan, Rui Miguel Da Silva Pinto, Agnetha Vave-Karamui, Cesar Villanoy, Marthen Welly, and Alan T. White.

Address correspondence to Rebecca Weeks, ARC Centre of Excellence for Coral Reef Studies, James Cook University, Townsville, Queensland 4811, Australia. E-mail: Rebecca.weeks@ @ jcu.edu.au 
${ }^{17}$ Conservation International Timor-Leste, Dili, Timor-Leste

${ }^{18}$ Rai Consultadoria, Dili, Timor-Leste

${ }^{19}$ Ministry of Environment, Climate Change, Disaster Management \&

Meteorology, Honiara, Solomon Islands

${ }^{20}$ The Nature Conservancy, Honolulu, Hawaii, USA

The Coral Triangle Marine Protected Area System aspires to become a region-wide, comprehensive, ecologically representative and well-managed system of marine protected areas (MPAs) and MPA networks. The development of this system will proceed primarily through the implementation of ecological, social, and governance MPA networks at the sub-national scale. We describe six case studies that exemplify different approaches taken to develop MPA networks in the Coral Triangle region at different scales: Nusa Penida in Indonesia; Tun Mustapha Park in Malaysia; Kimbe Bay in Papua New Guinea; Verde Island Passage in the Philippines; The Lauru Ridges to Reefs Protected Area Network in Choiseul, Solomon Islands; and Nino Konis Santana Park in Timor Leste. Through synthesis of these case studies, we identify five common themes that contributed to successful outcomes: (1) the need for multi-stakeholder and crosslevel management institutions; (2) the value of integrating cutting-edge science with local knowledge and community-based management; (3) the importance of building local capacity; (4) using multiple-use zoning to balance competing objectives; and (5) participation in learning and governance networks. These lessons will be invaluable in guiding future efforts to expand the Coral Triangle Marine Protected Area System, and provide important insights for MPA practitioners elsewhere.

Keywords community-based management, conservation planning, marine protected areas, marine protected area networks, marine reserves, multiple-use zoning

\section{Introduction}

The Coral Triangle Initiative for Coral Reefs, Fisheries and Food Security (CTI-CFF) is a multilateral partnership founded on the commitment of six countries in the Coral Triangle (Indonesia, Malaysia, Papua New Guinea, Philippines, Solomon Islands, and Timor-Leste) to address threats to their marine, coastal, and small island ecosystems through accelerated and collaborative action. The CTI-CFF has identified six strategic goals to achieve conservation outcomes and sustainable use of coastal marine resources. One of these goals is to establish a region-wide, comprehensive, ecologically representative and well-managed Coral Triangle Marine Protected Area System (CTMPAS) (CTI-CFF 2009). It is envisaged that the CTMPAS will be composed of marine protected areas (MPAs) and MPA networks that are connected, resilient, sustainably financed, designed to conserve the region's rich biological diversity and generate significant livelihood and food security benefits for coastal communities (CTI-CFF 2009).

Despite rapid growth in the number of individual MPAs within the Coral Triangle (initiated by communities, and local and national governments), a relatively small number are effectively managed, and few have been planned to form ecological networks (Weeks et al. 2010b; White et al. 2014). A critical stage in the progression from individual MPAs to a region-wide CTMPAS is the development of effectively managed sub-national MPA networks. By protecting a representative sample of biodiversity features, covering sufficient extent to encompass ecological processes, and facilitating species movement between protected sites through connectivity, ecological MPA networks can fulfill conservation, fisheries, and other objectives more effectively and 


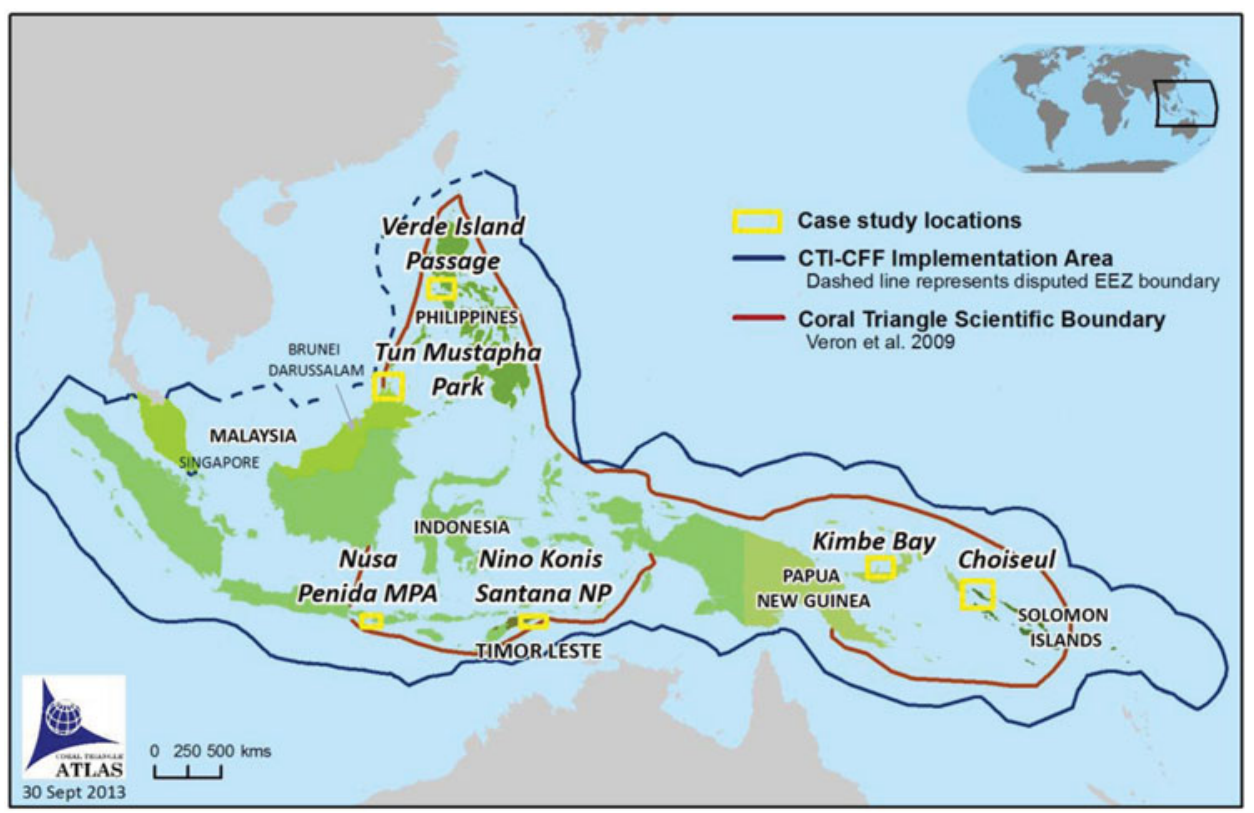

Figure 1. The Coral Triangle Initiative for Coral Reefs, Fisheries and Food Security implementation area, showing the location of the six case studies discussed in the article.

comprehensively than individual, unconnected MPAs (e.g., McCook et al. 2009; McLeod et al. 2009; Green et al. 2014). Social and governance networks allow communities to manage common resources collectively, for example through exchange of information and coordination of responsibilities and resources for management. This provides incentives for communities to coordinate actions across larger regions and to establish management more extensively than they otherwise might (Cumming, Cumming, and Redman 2006; Eisma-Osorio et al. 2009; Horigue et al. 2012).

The science of MPA network design and implementation has largely derived from nations with social, economic, and governance characteristics that differ greatly from those in the Coral Triangle (Christie and White 2007; Cinner 2007; Ban et al. 2011). These differences include highly diverse and complex institutional arrangements, such as fine-scale management jurisdictions (Weeks et al. 2010a) and customary ownership of resources (Cinner et al. 2012), high rates of poverty, and a much higher dependence on marine resources for food security and income. This means that approaches to designing and implementing MPA networks pioneered in other countries (e.g., Fernandes et al. 2005) are not necessarily transferable (Christie et al. 2009). A further challenge to developing the CTMPAS is the diversity of social, economic, and governance systems, and differing capacity within the region (Cruz-Trinidad et al. 2014; White et al. 2014). Nevertheless, recent reviews of marine protected area science (Green et al. 2014), along with successes and failures in implementation in developing countries (Green et al. 2011), have produced specific guidance on how to improve the design and implementation of MPAs and MPA networks in the Coral Triangle. 
Here we present six case studies, one from each of the Coral Triangle countries (Figure 1), which exemplify different approaches that have been taken to develop MPA networks in this region. Some networks (e.g., Verde Island Passage, Philippines; The Lauru Ridges to Reefs Protected Area Network, Solomon Islands) have evolved from the bottom up, through careful coordination of existing small MPAs into strategically planned and scientifically informed MPA networks. Others (e.g., Nusa Penida, Indonesia; Tun Mustapha Park, Malaysia; Nino Konis Santana Park, Timor-Leste) were formed through the declaration of a large marine protected area, and later refined to achieve their objectives through multiple-use zoning. Yet others (e.g., Kimbe Bay, Papua New Guinea) have been designed to form ecologically connected networks (Green et al. 2009) from the outset. All of the case studies involve close consultation with local communities in the management of their natural resources.

While each case study is framed within a particular social, political and ecological context, we identify several common themes underlying successful outcomes. These provide important insights to guide future efforts to expand the CTMPAS, which also have value for MPA practitioners elsewhere.

\section{Case Studies}

\section{Resolving Conflict between Tourism, Culture, Seaweed Farming, and Fisheries in Nusa Penida, Indonesia}

The Nusa Penida MPA is located off the southeast coast of Bali Island, Indonesia, and covers $200 \mathrm{~km}^{2}$ of coastal waters surrounding the three main islands of Penida, Lembongan, and Ceningan (Figure 2). The MPA contains a variety of critical marine ecosystems, including coral reefs, mangroves, and seagrass beds. Marine biodiversity surveys conducted in 2008 documented 298 species of coral and 576 species of fish, including five new species (Allen 2008; Turak and De Vantier 2009).

Nusa Penida's 45,000 inhabitants are highly dependent on fisheries, seaweed farming, and marine tourism as their main sources of income. Local fishermen target schools of small pelagic fishes that form in the strong currents between Bali and Lombok, reef fish and sharks. Seaweed farming covers extensive areas of reef flat around all islands and provides regular income for many local families. Tourism is concentrated on Nusa Lembongan, which is world-famous among divers for the aggregations of sunfish (Mola mola) and manta rays that occur predictably each year. This makes Nusa Penida MPA one of the most-visited marine tourism destinations in Bali, with more than 200,000 visitors each year.

The community in Nusa Penida has a traditional law, an awig-awig, to protect their coastal resources. Every year the community conducts a traditional Nyepi Segara ceremony where people are not allowed to conduct any activities on the sea, and access to and from Nusa Penida is closed for one full day. This ceremony demonstrates respect for the sea, which provides income for the community throughout the year, allowing it a day of rest.

Intensive utilisation of coastal resources in a relatively small coastal area means the potential for conflict among these activities is high. Conflict has arisen between tourism and fisheries, between tourism and seaweed farming and between local communities and tourism operators. Nusa Penida MPA was established to protect the marine biodiversity of the area and to reduce conflict among these resource users for the benefit of local communities. 


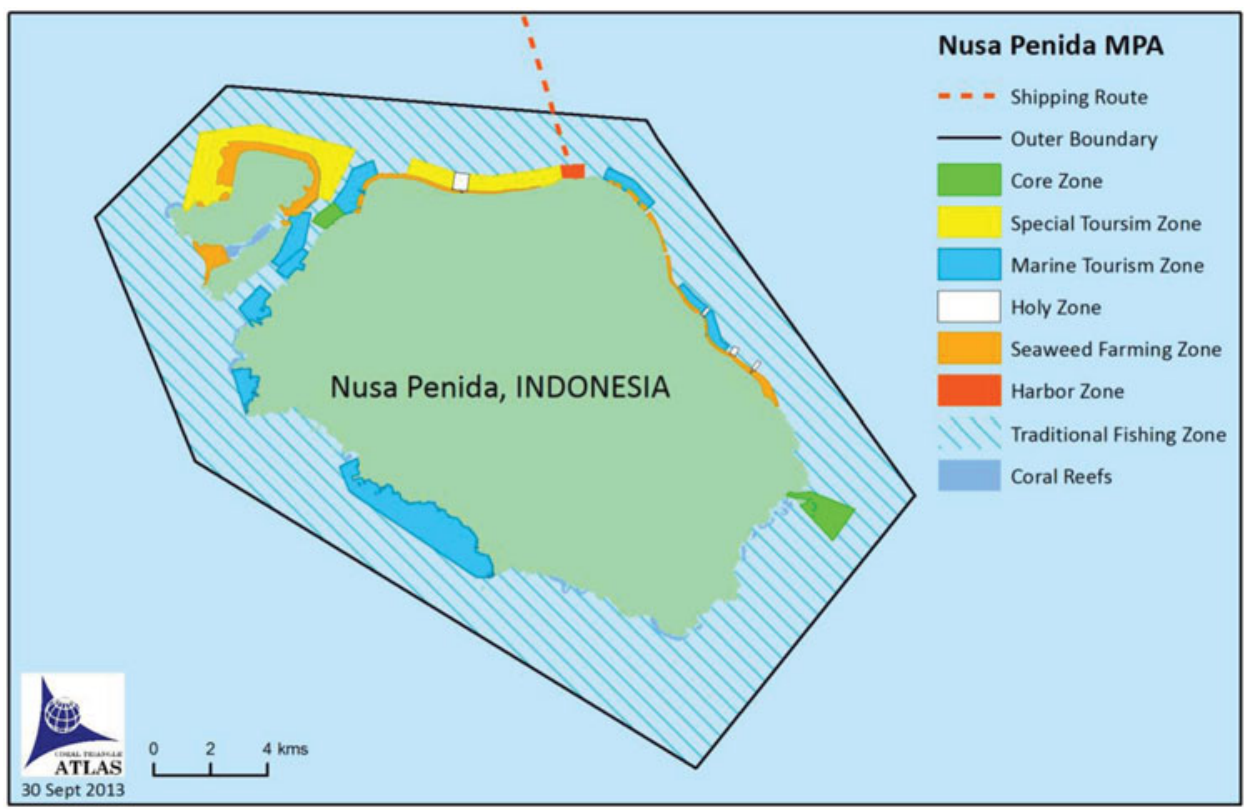

Figure 2. The Nusa Penida MPA zoning plan.

Nusa Penida MPA was declared by decree of the Head of Klungkung Regency (District) in 2010 and endorsed by a national Ministry of Marine Affairs and Fisheries (MMAF) decree. The Nature Conservancy (TNC) and The Coral Triangle Center (CTC) have supported the process of establishing the MPA. Progress to date includes: collection of biophysical and socioeconomic baseline data, inputs and agreement from key stakeholders on MPA establishment; development of a multi-stakeholder task-force; delineated and agreed-on MPA boundaries; completion of a zoning system based on scientific data and stakeholders' inputs through a series of public consultations; completion of a long-term management plan (20 years) including an action plan for the first 5 years; and joint patrols established between government and community representatives. The Nusa Penida MPA exemplifies the shift towards decentralized management of marine resources in Indonesia, which occurred following the 2004 Decentralization Act and 2007 Government Regulation on Fisheries Resources Conservation. At present, local governments manage more than 50 MPAs in Indonesia; these complement nationally designated MPAs.

The Nusa Penida MPA zoning plan (Figure 2) includes seven zones, which are marked using mooring buoys to indicate boundaries. In the largest zone, the $171-\mathrm{km}^{2}$ sustainable fishery zone, fishermen are allowed to fish only using non-destructive methods. Fishermen may also fish in the $9.1-\mathrm{km}^{2}$ special use zone, but only from $4 \mathrm{pm}$ to $9 \mathrm{am}$. The $2.1-\mathrm{km}^{2}$ core zone is reserved for education and research purposes, with all fishing and tourism activities prohibited. Fishing is also prohibited in the $12.2-\mathrm{km}^{2}$ marine tourism zone. The two notake zones (core and tourism) include reefs with high coral diversity and potential reef fish spawning aggregation sites; the marine tourism zones include feeding and cleaning stations for sunfish and manta rays. To prevent conflict between seaweed farming and tourism, the plan includes a $4.6-\mathrm{km}^{2}$ zone set aside for seaweed farming. In keeping with local culture and tradition, the zoning plan includes a sacred zone around the temple on the coast, in 
which the use of speedboats is prohibited. Tourists can dive in this zone, but only within a limited area marked by buoys. The last zone comprises the seaport, where a ferry operates to take passengers to Bali.

Nusa Penida MPA was designed to protect unique and endangered species that are a focus for tourism activities, including the sunfish and manta ray aggregations. To address the negative impacts of tourism on the environment, a marine tourism code of conduct has been developed for operators, based on scientific data and through agreement with the tourism operators. The code of conduct regulates divers' and snorkelers' activities while ensuring they can enjoy Nusa Penida's marine biodiversity.

A multi-stakeholder Nusa Penida MPA management unit has been established, with a joint patrol team, biophysical monitoring team, and socioeconomic monitoring team, comprising representatives from government, the Indonesian Navy, Nusa Penida Fishermen's Forum, local dive operators, the tribe council (Majelis Alit), nongovernmental organizations (NGOs) and communities. The management unit will be responsible for implementing the zoning and management plan, marine tourism code of conduct, and collecting entrance fees from marine tourism activities. These fees will provide a financing mechanism for the MPA. Nusa Penida MPA has been established as learning site for Indonesia and the Coral Triangle, where people can come to learn about processes for MPA and MPA network establishment. Site-based training is conducted on reef health and resource use monitoring, MPA basic principles and design, zoning plan and management plan development, and financing mechanisms.

\section{Multiple-Use Zoning in Tun Mustapha Park, Malaysia}

Tun Mustapha Park (TMP) covers a large area of 10,200 $\mathrm{km}^{2}$ of marine and coastal habitat located at the northern tip of Borneo, Sabah, Malaysia, within the Sulu-Sulawesi Marine Ecoregion. The region is a global conservation priority for its marine life, encompassing a rich diversity of coral reef, mangrove, and seagrass habitats as well as several rare and endangered species, including dugongs, sea otters, humpback whales, and sea turtles (Conservation Plan for the Sulu-Sulawesi Marine Ecoregion 2003). The region is also home to over 187,000 people, almost half of who depend on marine resources for their livelihood and wellbeing. The three districts within TMP are among the poorest in Sabah. Fishing is the primary economic activity in the region, contributing $22 \%$ of total marine fisheries production in Sabah in 2008. Trawl and purse seine fisheries are the largest fisheries in the region; other significant fisheries include the live reef fish trade, long line and small-scale hook and line, and gill net artisanal fisheries (Teh, Cabanban, and Sumaila 2005).

In 2003, the Sabah State Government approved an initiative to gazette and zone TMP for multiple uses, including conservation and fishing. Three goals were established for the Park: (1) to eradicate poverty; (2) to ensure sustainable development; and (3) to conserve habitats and threatened species. To achieve these goals while balancing alternative uses within the TMP, a comprehensive zoning system was developed through collaboration between Sabah Parks, WWF-Malaysia, The University of Queensland, and stakeholders within TMP (with support from USAID's Coral Triangle Support Partnership).

In 2011, a multi-agency and multi-stakeholder Interim Steering Committee was established to guide the development of a management plan for TMP. Six technical working groups were established to focus on different aspects of management, one of which was zoning the TMP for multiple uses (the zoning working group). Stakeholders and decisionmakers explored a variety of methods for creating multiple-use zoning plans, and chose to use the systematic conservation planning software Marxan with Zones (Watts et al. 


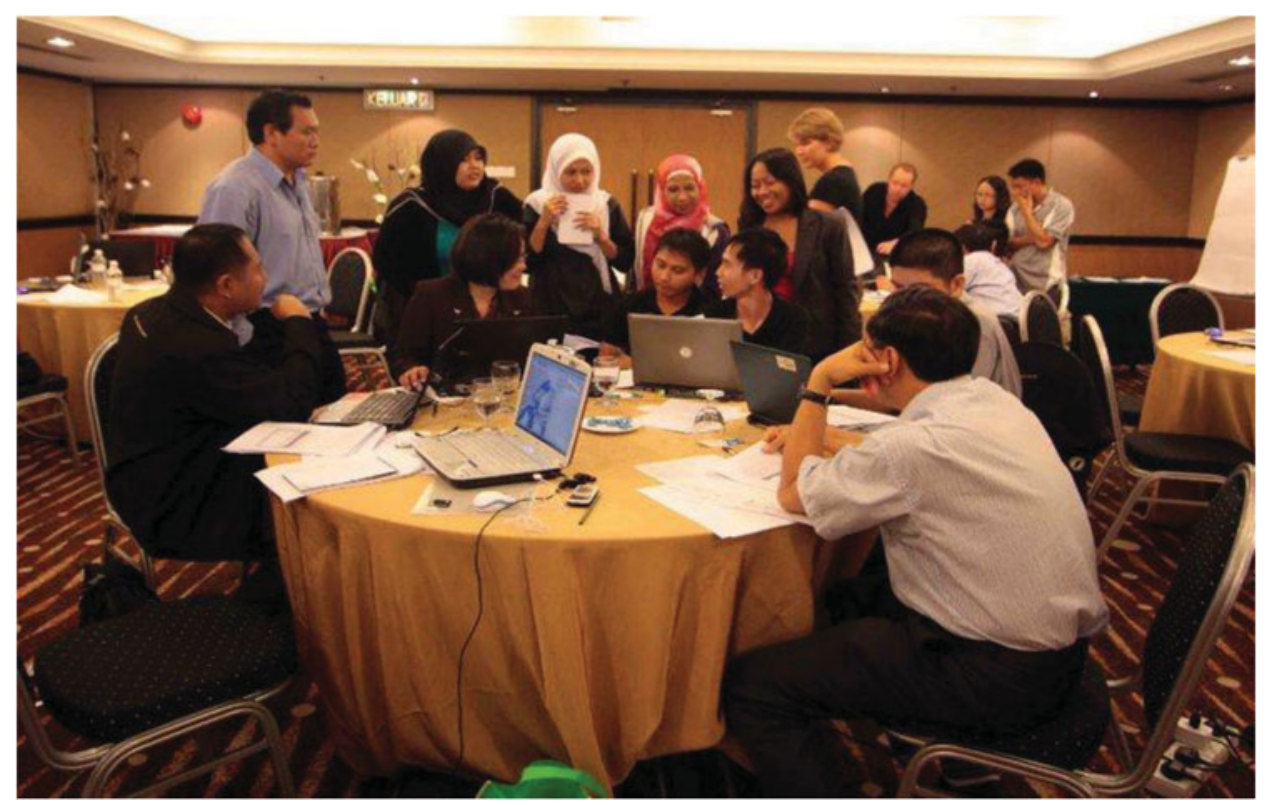

Figure 3. Stakeholders from Tun Mustapha Park participating in a Marxan with Zones course (credit: WWF-Malaysia/Irwanshah Mustapa).

2009). Marxan with Zones offers a method that is repeatable, transparent, and scientifically credible (Watts et al. 2009; Klein et al. 2010); however, its effective use requires technical expertise. To build the capacity of stakeholders within the region, WWF-Malaysia and Sabah Parks coordinated three Marxan with Zones courses, taught by researchers from The University of Queensland and attended by 30 people from 10 different agencies involved in zoning the TMP (Figure 3).

Existing coastal regulations provided a foundation for the zoning analysis. Throughout Malaysia, two major marine zones are defined by distance from the coastline: the "traditional fishing zone" within three nautical miles from the shore, and the "commercial fishing zone" beyond three nautical miles. The TMP zoning process focused on the traditional fishing zone, which contains the habitats under consideration for protection. Commercial fishing activities such as purse seining undertaken beyond three nautical miles from shore were not considered by the zoning plan.

The zoning working group used the best available ecological and socioeconomic data to develop a potential zoning plan. Two main types of data were collected from scientific surveys and local knowledge: conservation features, including habitat and species data; and patterns of resource use, which included the location of villages and spatial distribution of fishing effort. Existing effectively managed protected areas were automatically assigned to the appropriate zone, while areas that were identified as unavailable (e.g., populated coastal areas) or unsuitable for conservation (degraded marine habitat adjacent to Kudat, a major town) were excluded from the zoning analysis.

Marxan with Zones was used to identify priority areas for three different zones: preservation zones, in which extractive activities are prohibited; community-managed zones, where non-destructive small-scale and traditional fishing activities are allowed; and multiple-use zones, where non-destructive and small-scale fishing and other sustainable 
development activities (e.g., tourism) are allowed. To address the management goals of TMP (poverty alleviation, sustainable development, conservation), a suite of biophysical and socioeconomic design principles were developed by multiple stakeholders (Lee and Jumin 2007; Green et al. 2014). Where possible, these were used to guide the Marxan with Zones analysis; for example, representation and replication of habitat types, special and unique sites was explicitly considered by the software, whereas habitat adjacency and zone spacing were achieved through post-hoc analysis of outputs.

TMP was divided into four different ecological regions on the basis of potential influence of sea currents and wind movements on the development of coral reef ecosystems. To address the biophysical design principles, at least $30 \%$ of each habitat type (eight coral reef habitats defined by morphology and exposure, seagrass, and mangroves) and special feature (limestone caves, turtle nesting and feeding areas, dugong habitat) in each ecological region was required to be represented in the preservation zone.

To address the socioeconomic principles, impacts on fishing communities within TMP were minimized by ensuring maintained access to fishing grounds and by prioritizing fishing grounds close to communities for inclusion in either community-managed or multiple-use zones. To ensure the sustainability of traditional and non-destructive fishing practices, at least $70 \%$ of small-scale fishing grounds (within three nautical miles) were required to be included in either community-managed or multiple-use zones. Certain commercial fishing activities, such as long line, and recreational fishing are permitted within the multiple-use areas but not within the community-managed zone. To ensure that fishing communities could benefit from the spillover of adult fish from preservation zones, these were preferentially located adjacent to community-managed zones.

The draft zoning plan created in October 2012 is currently undergoing review and revision through a stakeholder consultation process. The government aims to fully implement the zoning plan by 2015 , once it has been endorsed by the Interim Steering Committee and approved by the Sabah government. As a large multiple-use protected area, TMP will be managed collaboratively by all stakeholders. It is hoped that the Interim Steering Committee will evolve into a governing body for TMP. The role of local communities in resource management will be recognized and community participation will be achieved through management of community-managed zones.

\section{Ecological, Institutional, and Social Connectivity in the Verde Island Passage, Philippines}

Also within the Sulu-Sulawesi Marine Ecoregion, the Verde Island Passage (VIP) marine biodiversity corridor covers an approximate area of $4,947 \mathrm{~km}^{2}$ (Figure 4). VIP is home to critically endangered species of marine mammals and turtles, along with populations of economically important pelagic and reef-associated fish species (Conservation International Philippines 2009). VIP was first identified as a conservation priority during the Philippine Biodiversity Conservation Priority-Setting Program in 2000 (Ong, Afuang, and RoselleAmbal 2000); the region's importance was further reinforced when Carpenter and Springer $(2005,1)$ declared the VIP to be: "the centre of the centre of marine shorefish biodiversity." The passage is threatened by multiple human activities such as unregulated fishing, tourism and shipping. VIP is a major shipping lane with vessels passing through to reach the international ports of Batangas, Manila, and Subic Bay and toward the other seascapes of the Visayas and Sulu Sea.

Recognition of the ecological significance of, and threats to, the VIP, led the Philippine government to establish the Sulu-Sulawesi Marine Ecoregion and the VIP as national 


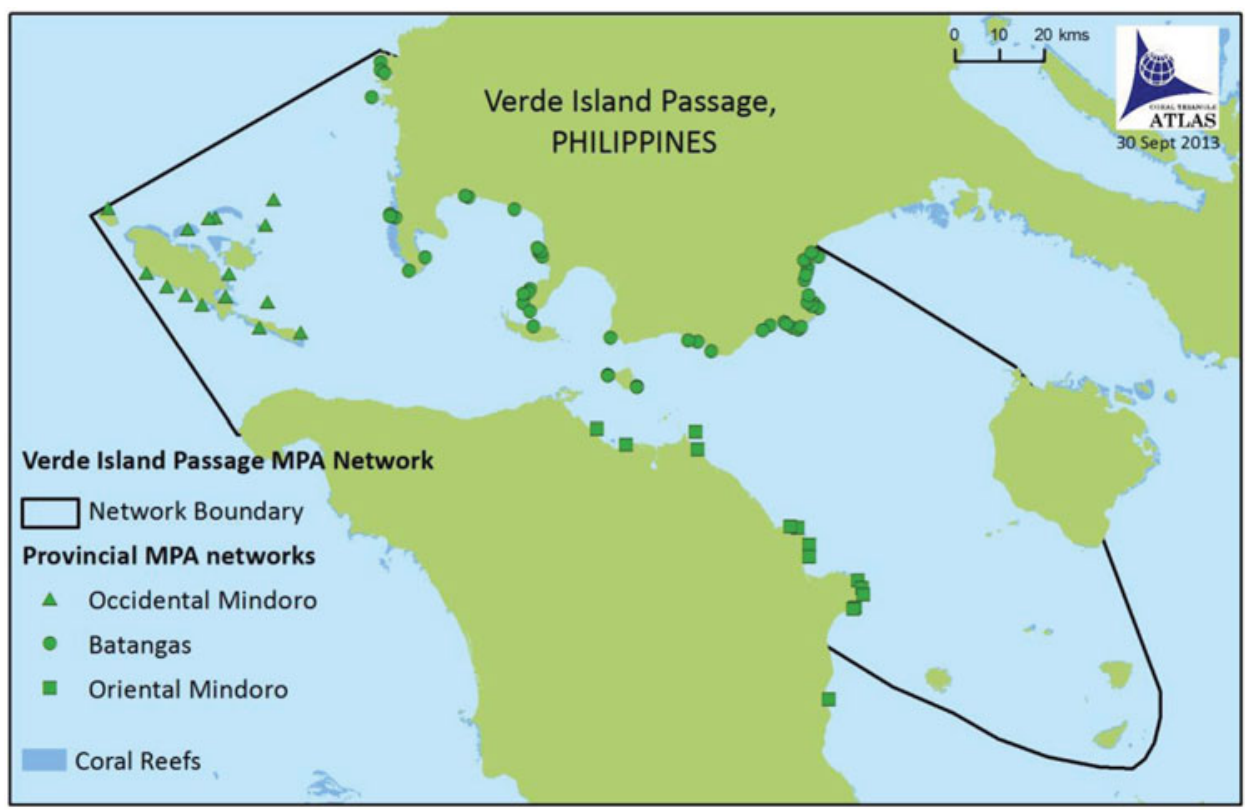

Figure 4. The Verde Island Passage Marine Protected Area Network, showing extent of three prior governance networks: the Batangas Province MPA and Enforcement Network, Oriental Mindoro Province MPA and Enforcement Network, and Lubang and Looc MPA Network in Occidental Mindoro Province.

priorities for biodiversity conservation. However, efforts to protect biodiversity and sustainably manage human activities within the passage are largely enacted by the local governments who have jurisdiction over coastal waters, with assistance from various government, nongovernment, and private institutions (Vergara et al. 2008).

The VIP MPA Network (VIP MPAN) was established with assistance from Conservation International (CI)-Philippines through the Sulu-Sulawesi Seascape Programme (Conservation International Philippines 2009). CI played a lead role in the initial design of a network of MPAs in the VIP based on ecological criteria (e.g., extent and condition of marine habitats, occurrence of marine megafauna and seabirds) and results from community surveys (e.g., spatial distribution of fisheries resources, land-based and marine threats, resource use and activities) (Conservation International Philippines 2009). The MPA network design has since been revised to maximize connectivity among MPAs (Quibilan et al. 2008), making the VIP MPAN one of the first MPA networks in the Coral Triangle to incorporate connectivity objectives. This was achieved through engagement with scientific experts and private institutions, to initiate research projects that identified potential areas for MPA establishment, and create partnerships to strategize and implement MPAN plans (Vergara et al. 2008).

In 2006, the University of the Philippines Visayas (Campos et al. 2007) and the University of the Philippines Marine Science Institute (Villanoy, Magno-Canto, and Cabrera 2007) were asked to conduct surveys to determine larval source and sink areas in the SuluSulawesi Sea, including the VIP region. Results from these surveys were used to develop a passive dispersal model of connectivity, to show general current patterns in different seasons and to identify larval sources and sinks. The dispersal models showed that the net flow of 
current through the VIP shifts seasonally, and that interactions between wind, currents, island topography and bathymetry give rise to oceanographic features that can explain the distribution of surface chlorophyll distributions and in turn the abundance of larvae in the VIP. The VIP receives and can accumulate larvae from outside sources (e.g., nearby reefs in the West Philippine Sea [see also Melbourne-Thomas et al. 2011] and Tayabas Bay), but may also retain larvae spawned within the region (e.g., Balayan and Batangas Bays).

Results from the connectivity studies conducted in the VIP were used to inform the evolving design of the VIP MPAN, for example through translation into recommendations on where to locate future MPAs. The importance of increasing MPA size was also highlighted (EcoGov Project 2011). However, establishment of new MPAs and relocation and expansion of existing MPAs in the VIP would not have been possible without cooperation from local governments and NGOs. Planning for the establishment of the VIP MPAN involved the use of participatory processes in order to empower and increase the capacity of communities and local implementers (Vergara et al. 2008). Participatory decision-making was facilitated through the formation of smaller networks within the region: the Batangas Province MPA and Enforcement Network, Oriental Mindoro Province MPA and Enforcement Network, and Lubang and Looc MPA Network in Occidental Mindoro Province (Figure 4). Partnerships between these networks were forged to create the larger VIP MPAN. Before these networks were formed in 2008 , about $7.6 \mathrm{~km}^{2}$ and $4.5 \mathrm{~km}^{2}$ were protected in Batangas Province and Oriental Mindoro Province, respectively, and not all MPAs were effectively managed. After the networks were formalised in 2011, protected areas increased to a total of $170 \mathrm{~km}^{2}$. Management effectiveness ratings of these MPAs also increased during this period (Horigue et al. 2012).

The formation of the smaller MPA and enforcement networks within the VIP increased the understanding of each local government of the need to have a unified vision and to coordinate their efforts in order to function more effectively. Furthermore, involvement of higher-level governance institutions (i.e., provincial governments) allowed for more efficient communication, buy-in, and coordination. This also facilitated accountability among the members of the networks, as the higher-level governance institutions were responsible for tracking the progress of each local government within the network (Horigue et al. 2012).

Currently, the VIP MPAN includes two cities and 20 municipalities, with 69 notake MPAs covering an area of $170 \mathrm{~km}^{2}$. While most MPAs are small $\left(<1 \mathrm{~km}^{2}\right)$ as is typical throughout the Philippines, eight are larger than $10 \mathrm{~km}^{2}$. The size and number of MPAs is increasing, with site selection guided by the results of the connectivity study, and management effectiveness improving as a result of governance networking. Incentives to improve management are provided through recognition of good practices, for example, the Batangas Recognition Awards for Verde Passage's Outstanding (BRAVO) Marine Protected Areas. VIP is a U.S. Coral Triangle Initiative Integration and Learning Site, and efforts are currently focused on conducting an independent evaluation of management effectiveness (using the system adopted by the Philippine MPA Support Network: White et al. 2006), and using these results to improve management.

\section{Moving from Scientific Design to Community Management in Kimbe Bay, Papua New Guinea}

Kimbe Bay is located on the north coast of New Britain Island in the Bismarck Sea, Papua New Guinea (PNG). It is a large $(140 \mathrm{~km} \times 70 \mathrm{~km})$, well-defined bay, which comprises a wide variety of shallow and deep-water marine habitats of high conservation value (Green et al. 2009). Rapid ecological assessments have described healthy and diverse 
coral reefs, mangrove forests, and seagrass beds, as well as important habitats for rare and threatened marine mammals, turtles, and seabirds. Coastal ecosystems are facing increasing pressure from clearance of forests and mangroves, changes in land-use practices, and runoff of sediment and pollutants from industrial agriculture, forestry, and subsistence agriculture (Green et al. 2009). Overfishing is not yet a serious problem, with the exception of commercially important invertebrates. However, the use of destructive fishing methods (dynamite) has been a problem in the past.

Approximately 100,000 people live in Kimbe Bay, a third of whom have migrated from elsewhere to provide labour for the large oil palm industry in the province. Coastal communities rely on both land and marine resources to meet their subsistence and cash income needs, and much of their cultural identify, beliefs, and ancestral stories are drawn from the marine environment (Koczberski, Curry, and Warku 2006). As in other parts of PNG, ownership of the land and sea resources is clan-based, and communities make decisions on local conservation and resource management.

In 2006, TNC provided technical support for the design of a resilient network of MPAs, which was one of the first of its kind in the Coral Triangle (Green et al. 2009). In moving from a scientific design process towards implementation and governance of the MPA, TNC is now working to build the capacity of local partner organizations to take on a leadership role.

The MPA network design was based on a scientific assessment of biodiversity and socioeconomic values, and identified 14 Areas of Interest (AOIs) that met specific conservation goals (Figure 5). The objectives of the network were twofold: to conserve marine biodiversity, and to address local marine resource management needs. A wide range of stakeholders participated in scientific design workshops including academia, government, and NGOs. While communities were not directly involved in the design phase, there was

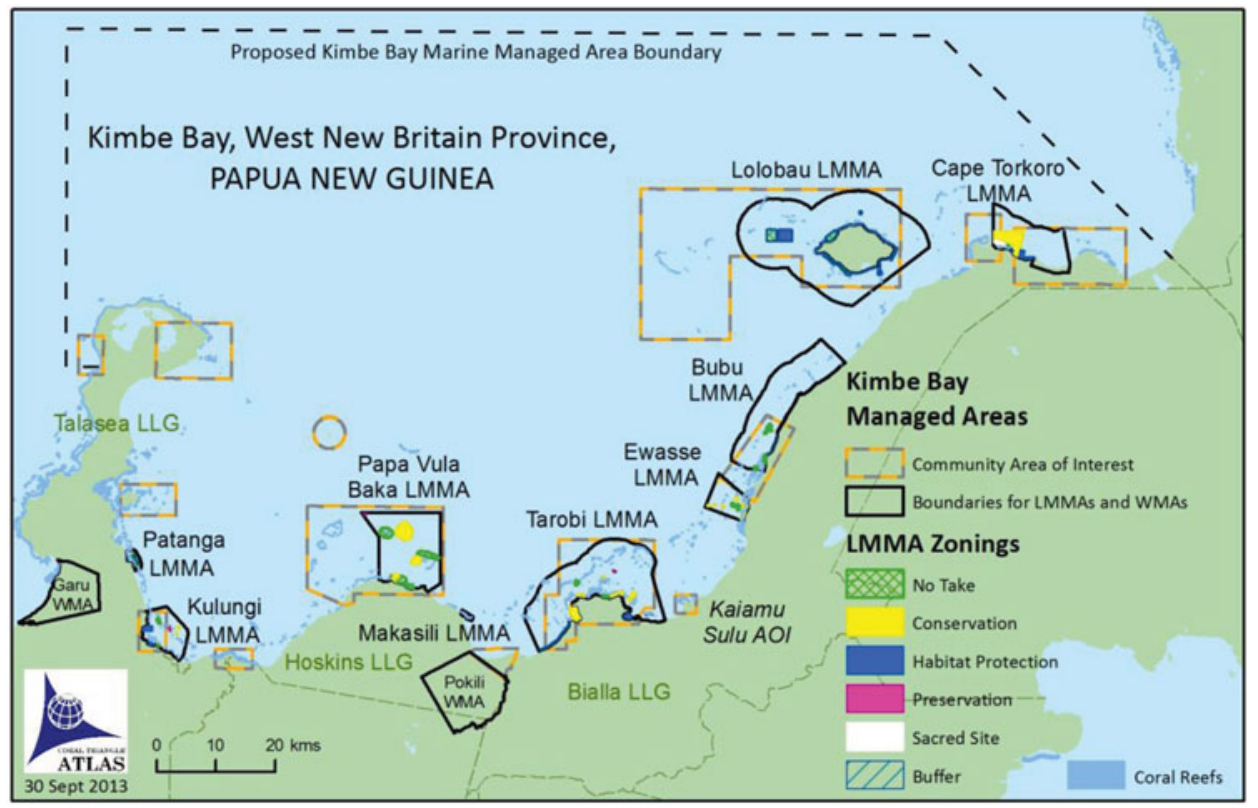

Figure 5. The Kimbe Bay Marine Management Area, showing LMMAs established within Areas of Interest (AOIs) to date. 
good local support for marine conservation following activities to raise communities' awareness of the value of their marine resources and the need to protect them from destructive human activities.

Since 2006, TNC has supported a community-based planning process to refine and implement the MPA network design by establishing locally managed marine areas (LMMAs) within the AOIs. This process involves six steps: (1) community engagement; (2) community visioning; (3) participatory conservation planning; (4) community development of a LMMA plan; (5) preparation of a draft plan and agreement; and (6) stakeholder consultation and finalization of the plan and agreement by the community (Green et al. 2009).

To date, 14 communities have established nine LMMAs in seven of the AOIs (Figure 5). There is considerable variation in the size and zoning of these areas, with some managed cooperatively by several communities. Individual LMMAs are conducting regular biological monitoring and surveillance with limited support from TNC, who provided training for a local community monitoring team. In 2011, TNC trained a local team from the Bialla LMMA to coordinate the six-step community engagement process directly with communities in the AOIs where implementation has yet to take place. This team has been working in the Kaiamu Sulu AOI, where a draft management plan has been completed and will be launched in 2013.

Substantial progress has also been made toward establishing a governance and management framework for the MPA network. At the local level, marine environmental management and protection laws were created for the three local-level governments with marine areas (Talasea, Hoskins and Bialla); these laws form the basis of LMMA management plans developed by the communities. At the provincial level, TNC signed a Memorandum of Understanding with the West New Britain government to develop a governance system for the Kimbe Bay Marine Management Area including establishing a governing Secretariat. A Steering Committee comprising members from NGOs, government, and private sectors was established, and has now taken ownership of this process.

Under the guidance of the Steering Committee, the provincial government has provided support for the implementation process: purchasing boats to support biological monitoring and enforcement in four of the established LMMAs; hosting a site visit to the Tarobi LMMA; facilitating the allocation of a budget to support the LMMA program; and co-financing training and socioeconomic surveys for two LMMAs. The provincial government intends for the Secretariat to eventually become a division within the Department of West New Britain. TNC will continue to support the institutional development of the Secretariat to ensure a Kimbe Bay wide management plan that incorporates climate change and fisheries principles is further developed and adopted.

The LMMA communities in Kimbe Bay are now part of the newly established PNG Learning and Training Network. This network aims to identify good practice tools and methods for community conservation and resource management, and share these through learning exchanges. Many lessons from Kimbe Bay are eye opening for other communities in PNG who are just beginning to plan resource management initiatives.

\section{The Lauru Ridges to Reefs Protected Area Network, Solomon Islands}

Choiseul (known locally as Lauru) is one of the nine provinces of Solomon Islands (Figure 6). Choiseul supports the highest terrestrial biodiversity in the Solomon Archipelago (Diamond 1976; Morrison, Pickacha, and Pitakia 2007) and its marine habitats remain lightly exploited and in good health (Green et al. 2006). Choiseul has the lowest population density in Solomon Islands, with the majority of people living in coastal villages, practicing 


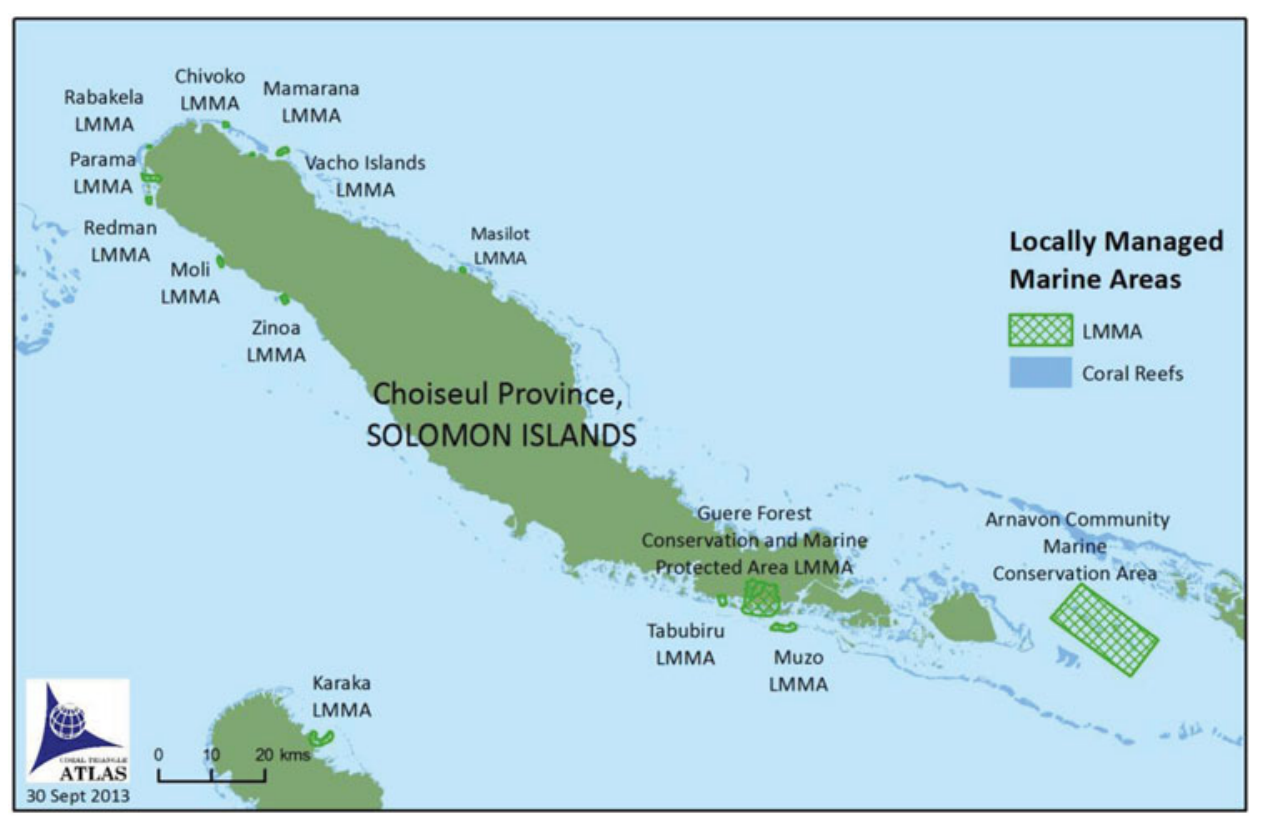

Figure 6. The Lauru Ridges to Reefs Protected Area Network.

a subsistence-based lifestyle and retaining customary ownership of their land and shallow seas.

Over the past decade TNC has worked closely with an indigenous NGO, the Lauru Land Conference of Tribal Community (LLCTC) and the Choiseul Provincial Government to establish community-based protected areas throughout Choiseul. By 2008, nine community-based protected areas were established through this partnership, and there was a ground swell of interest and enthusiasm among the community of Choiseul for establishing further marine and terrestrial protected areas. It was decided that a better knowledge of the biodiversity, threats, and opportunities in Choiseul was required, to ensure that implementation of future conservation areas by the LLCTC and partners could be carried out in a more strategic manner (Lipsett-Moore et al. 2010).

Previous experiences in community-based management in Choiseul and throughout Melanesia had shown that sociopolitical factors determine whether or not community-based conservation efforts are likely to be successful (Aswani and Hamilton 2004; Hamilton, Potuku, and Montambault 2011). The key factors that typically lead to success are: (1) protected areas conserve resources that are of value to local stakeholders; (2) protected areas are established on customary lands and seas that are free from ownership disputes; and (3) communities understand what it means to establish a protected area, and are supportive of it. In an attempt to capture these elements across Choiseul, a conservation plan that involved broad stakeholder participation and the documentation of local knowledge was developed.

In May 2009, a stakeholder workshop was held in Taro, the provincial headquarters of Choiseul. The workshop was attended by 45 stakeholders, the majority of whom were chiefs and leaders from across the province (Lipsett-Moore et al. 2010). The workshop began with participants listing all of the features in their province that they recognized as being of conservation value. Local features that were identified included turtle nesting 
beaches, fish spawning aggregations, megapode nesting areas, ironwood forests, and lakes. Workshop participants were provided with large format colour maps of their customary estates that illustrated terrestrial and reef habitats (identified from existing GIS databases of vegetation and marine biodiversity of Choiseul: Lipsett-Moore et al. 2010), rivers, roads, and major communities at 1:70,000 scale. Participants then used their local knowledge to identify where local conservation features occurred within their customary lands and seas, local threats to marine and coastal resources, and areas proposed for conservation.

To identify good opportunities for conservation in Choiseul, stakeholders used participatory mapping to demarcate regions of their customary lands and seas that they felt would be suitable. These areas were selected on the basis of participant's knowledge of the sociopolitical conditions of their customary estates, and included areas that had good community support for conservation, areas proposed as protected areas, and areas that already had some form of traditional management in place.

In total, 78 distinct local features were identified and digitized into GIS format and 25 were used in the final analysis. The conservation planning software Marxan was used to assist with the design of a series of maps showing what a Lauru Ridges to Reefs Protected Area Network with goals of protecting $10 \%$ or $20 \%$ of the total area of 89 classes of terrestrial and aquatic habitats, 47 classes of marine habitats, and the 25 locally identified features would look like (Game et al. 2011). Conservation opportunities were incorporated in the Marxan analysis by making these areas less "costly" to include in protected area network designs (Game et al. 2011).

In late 2009, the LLCTC reviewed a draft Choiseul Conservation Plan, and endorsed the establishment of a Lauru Reefs to Ridges Protected Areas Network that would protect at least $10 \%$ of biodiversity and local conservation features across Choiseul. It was agreed that the implementation of new protected areas would remain a community driven process, with guidance from the Choiseul Conservation Plan. Since that time, six additional protected areas have been established in Choiseul. As anticipated, these new protected areas were established on land and seas where the sociopolitical factors that determine success could be met; how closely these geographies aligned with the high priority conservation areas identified in the Choiseul Conservation Plan was of secondary importance.

The greatest value of the Choiseul Conservation Plan has been its role in leveraging conservation efforts and influencing future developments across Choiseul Province. First, the conservation planning process galvanised support for a province-wide Reefs to Ridges Protected Areas Network. Second, the existence of the Choiseul Conservation Plan and its ownership by national and provincial governments has attracted additional environmental funding into Choiseul in recent years. Finally, the identification of conservation priorities across Choiseul has given stakeholders greater bargaining power when negotiating with mining companies and the national government about if, and where, future mining operations should be allowed to occur.

\section{Creating a Template for Co-Management in Nino Konis Santana Park, Timor-Leste}

The Nino Konis Santana (NKS) National Park, located on the eastern-most tip of TimorLeste (Figure 7), is the nation's first and only national park. Declared in 2007, five years after Timor-Leste's independence, the park encompasses over $1,236 \mathrm{~km}^{2}$ of terrestrial territory and $556 \mathrm{~km}^{2}$ of marine territory. NKS is home to numerous endangered and endemic species including the critically endangered Yellow-crested Cockatoo, the endemic Timor-Green Pigeon, and the endangered Timor Imperial Pigeon. In August 2012, a Marine Biodiversity Rapid Assessment Program (MRAP) conducted by Conservation International 


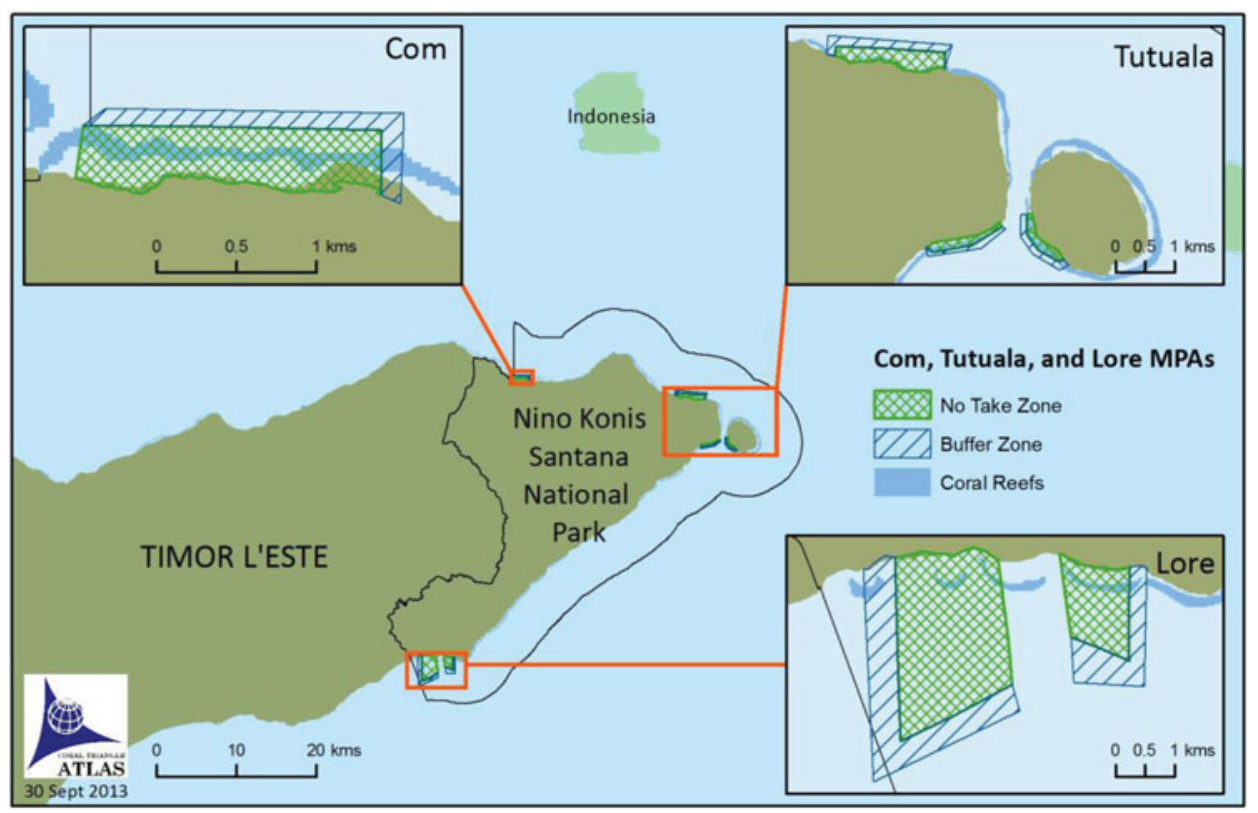

Figure 7. The Nino Konis Santana National Park.

(CI) confirmed that NKS has extremely high marine biodiversity. The MRAP team also reported that Timor-Leste's oceanography could provide a cool water buffer and refuge against increasing sea temperatures and associated coral bleaching events occurring as a result of climate change.

In addition to its high biological diversity and ecological importance, the marine environment of NKS is extremely important to the livelihoods of thousands of people living within the park. Fishing communities are directly reliant on marine and coastal resources for both food security and their livelihoods (Andrew, Pheng, and Philips 2011). The Timorese government is also focusing on nature-based tourism as a strategy for future economic development. This includes both dive tourism and plans to establish a tourism trail from Dili to NKS. Unfortunately, the marine and coastal environments of NKS are threatened by over-fishing, destructive fishing by foreign fishers, and in some areas by sedimentation from upland agriculture and forestry. These threats have the potential to be exacerbated by climate change impacts over the long term.

As Timor-Leste's first MPA, the focus for NKS has been to develop low-cost, effective management solutions with strong community participation, which might form a template for future implementation throughout the country. The government of Timor-Leste, supported by USAID's Coral Triangle Support Partnership (CTSP), has worked to develop a co-management approach to marine resource management with the communities in NKS. This work is being led through collaboration between CI and a local consulting firm, Rai Consultadoria. The central feature of this co-management approach is supporting community members and Government at the National, District, and Sucu (village) levels to develop the knowledge and key skills needed for effective marine resource and fisheries management. These include: facilitation, outreach, and awareness raising on marine ecology and the benefits of management, project planning, zoning and rule making, designing and 
implementing collaborative compliance and enforcement systems, biological and socioeconomic monitoring, reporting results to stakeholders, and financial management.

With CTSP's support, government and local leaders facilitated the communities through a comprehensive planning process to: identify priority resources, including species and habitats and their current status; identify major threats to those resources and their causes; and subsequently develop solutions to better manage their resources. Based on the outputs from these discussions, the team provided outreach on key ecological factors that should be considered when developing management actions. This included highlighting essential factors that will help to build resilience to threats from climate change. The proposed solutions formed the foundation for the development of a multiple-use zoning and regulatory scheme for NKS.

Marine zones within NKS include no-take zones, buffer zones, and special regulation zones, with a mix of gear restrictions, temporal closures, and species-specific take limits. This zoning scheme is accompanied by community-based management plans, and covers $223 \mathrm{~km}^{2}$ of the $556 \mathrm{~km}^{2}$ marine park (Figure 7).

CTSP also utilized planning tools to understand potential vulnerability of priority resources to climate change impacts and to develop adaptation activities. This included brainstorming with communities about impacts they had observed related to weather events, and solutions that they could propose. In the end, with the assistance of the government and CTSP team, the communities identified several adaptation activities that were subsequently included in their management plans. Examples of these include: re-vegetating key upland areas to reduce sedimentation and coastal erosion; improving water management systems; ensuring the design of no-take zones and fisheries areas follow the latest sciencebased management guidelines to build resilience; and diversifying income sources through development of small-scale tourism livelihoods.

The community-based zoning scheme was completed prior to the MRAP, and was based primarily on local knowledge and surveys completed by the local team trained by CTSP. Happily, the MRAP team (as well as previous research reported on in Edyvane et al. 2009) confirmed that the majority of the marine ecosystems with high conservation value were included in the areas that communities had selected as no-take areas for fisheries replenishment during the zoning process. Only a few key biodiversity features were not yet included in the community developed zoning scheme.

By conducting the expert surveys after the process of community-based zoning, the team has maintained a focus on community ownership of the process. That the MRAP team concurred with the community-selected areas has become a source of pride and motivation for the local community. Had the MRAP been held prior to the community process, the team feels strongly that it would have had the opposite effect of disempowering and demotivating the community. The result has instead been extremely empowering for communities and marine management in Timor-Leste overall.

Moving forward, the collaborative team working in NKS will hold additional consultations and planning sessions to fill the gaps in management identified by the MRAP. This will include the creation of additional no-take zones in a few high priority areas of NKS where none have yet been declared, and expanding existing no-take zones to include important features identified by the MRAP. The team is also focusing on effectively implementing the management, compliance, and enforcement activities of the community management plans.

The process of creating the zoning scheme and management plans has been an extremely successful example of co-management and collaboration across many levels of Government and communities. In addition to the establishment of an ecologically resilient 
network of no-take zones and other regulations within NKS, the process has also resulted in the emergence of informal social networks between communities from different parts of NKS and including local and national government staff. These stakeholders from different areas within NKS have regularly come together to work on key management processes and to share their knowledge and experiences. While these networks remain informal and meet only sporadically as management needs dictate and resources allow, this has created the foundation for the potential formation of more consistent learning networks across Timor-Leste. Sharing experience between site stakeholders that are more advanced in marine resource management and those that are newer to the process offers great potential to strengthen, and potentially speed, adoption of successful management practices. To aid in this learning process, the team has documented the model of practice for effective comanagement that was developed in NKS and will share these approaches with other sites in Timor-Leste and further afield.

\section{Discussion}

Each case study demonstrates a unique approach to MPA network design and implementation that has arisen out of specific cultural, governance, and regulatory conditions at each site. In all case studies, basic design principles for ecological MPA networks, such as the representation and replication of key biodiversity features within highly protected zones (Green et al. 2014), have been considered (although ecological connectivity information was only available for the Verde Island Passage and Kimbe Bay). All are supported by social or governance network structures, although these take different forms: local government alliances, multi-stakeholder management committees, indigenous organizations, and co-management arrangements.

Through synthesis of these examples, we have identified five common themes that contributed to successful outcomes: (1) the need for multi-stakeholder and cross-level management institutions; (2) the value of integrating cutting edge science with local knowledge and community-based management; (3) the importance of building local capacity; (4) using multiple-use zoning to balance alternative objectives; and (5) participation in learning and governance networks. While not all themes will be relevant in every situation, these strategies might serve as good practices to inform the expansion of the CTMPAS through the development of sub-national MPA networks.

1. The need for multi-stakeholder and cross-level management institutions. Mismatches between the spatial scale of ecological processes and the institutions that are responsible for managing them can lead to ineffective management of natural resources, and a subsequent decrease in social-ecological resilience and human well-being (Cumming, Cumming, and Redman 2006; Mills et al. 2010). Where management jurisdictions are small, as in the Coral Triangle, local-scale management alone is unlikely to lead to effective management of ecological processes, which typically operate across broader spatial scales (Berkes 2006; Mills et al. 2010). Scale mismatches can be overcome by engaging in management at multiple scales and levels through cross-level governance (e.g., local, provincial, and national) (Berkes 2006) and social learning (Cumming, Cumming, and Redman 2006).

Cross-level management institutions were particularly important in the Verde Island Passage, where the formation of smaller MPA networks, later joined to form the VIP MPAN and reinforced by provincial government support, fostered understanding, 
co-ordinated action, and accountability. Support from provincial governments was also a vital factor in reinforcing management in Choiseul Province and Kimbe Bay. An additional benefit to multi-level management structures is that they allow for local management autonomy, as is apparent in the site-specific community management plans in Nino Konis Santana, Tun Mustapha, and Kimbe Bay.

2. Integrating scientific information with local knowledge and traditions. MPA networks designed on the basis of both scientific information and local knowledge are likely to have better management outcomes, as a result of more effective design (Klein et al. 2008) and increased stakeholder support, which typically translates to compliance with management regulations (Russ and Alcala 1999). For example, the design of the MPA networks for Kimbe Bay and VIP were informed by connectivity science (e.g., Quibilan et al. 2008; Planes, Jones, and Thorrold 2009), but the implementation processes incorporate individual communities' visions for their environment. In Nino Konis Santana, important areas for fisheries and biodiversity conservation were first identified using the knowledge and priorities of local fishing communities and surveys by locally trained scientists. These areas were then confirmed and a few adjustments were suggested following expert biodiversity surveys. This process strengthened the overall involvement and conservation leadership of community members while also confirming that the highest value areas for conservation come under protection. The "holy zone" in the zoning plan for Nusa Penida MPA provides a further example of how zoning plans can integrate local customs.

Strategic partnerships with NGOs and research institutions can provide access to technical expertise (as in the case of the University of Queensland assisting planners in Tun Mustapha Park) and scientific information (as in the case of the connectivity models of the VIP developed by the University of the Philippines) that can greatly improve the scientific basis for management. Alternatively, participatory mapping of biodiversity features (as undertaken by community leaders in Choiseul and local stakeholders in Tun Mustapha) can provide local inputs to systematic conservation prioritizations.

Also apparent in our case studies is a need for local considerations to take precedence in some contexts. In Choiseul Province, the locations of new protected areas were primarily determined by local sociopolitical factors, with conservation value a secondary concern. In NKS, it was considered vital that the communitybased zoning scheme was completed prior to the scientific assessment to ensure community ownership of the planning process.

3. Building capacity for local responsibility and leadership. In all case studies, NGOs played a critical role in MPA network design and implementation. Local managers are typically dependent on assisting organizations (e.g., NGOs or academic institutions) for technical support to design MPA networks with regional-scale and science-based perspectives (Green et al. 2009; Game et al. 2011; Horigue et al. 2012). Nevertheless, our case studies offer good examples of how dependence on outside organizations can be reduced through capacity building designed to foster local leadership and responsibility for management.

In Tun Mustapha Park, specific training in conservation planning software (Marxan) enabled local stakeholders to participate in the technical aspects of MPA network design, resulting in a zoning plan that was locally owned, and not an outside product. While communities were not directly involved in the technical design phase of planning the MPA network for Kimbe Bay, capacity building activities have enabled local stakeholders to assume increasing responsibility through the 
transition to implementation; local teams now play a principal role in monitoring existing MPAs and leading community engagement processes to expand the network.

MPA network design should involve local stakeholders as far as possible, to ensure local ownership of, and commitment to, the planning process, since in countries with high resource dependence the success of any management and conservation endeavor is largely dependent on local buy-in (White, Courtney, and Salamanca 2002). Organizations providing technical and operational assistance should carefully plan their "exit strategy" early on, so that local capacity and leadership is cultivated, and management does not fail once support is withdrawn.

4. Multiple-use zoning to balance alternative objectives. MPA networks in the Coral Triangle are typically required to achieve multiple, sometimes competing objectives, and must represent the interests and priorities of a diverse range of stakeholders (Halpern, Klein, and Brown 2013). Multiple-use zoning of a large MPA offers a more flexible approach to resource management compared to MPA networks that comprise no-take zones only (Grantham et al. 2012). For example, marine zones within NKS include no-take zones, buffer zones, and other management zones with a mix of gear restrictions, temporal closures and species-specific take limits.

In Nusa Penida MPA, multiple-use zoning was used to resolve conflict between marine tourism, seaweed farming and fisheries activities, ensuring that all stakeholder groups' interests were clearly represented in the plan. Zoning also provided a way to integrate cultural considerations into the management plan, through a sacred zone adjacent to the temple in which diving and boating activities are restricted. Similarly, other traditional management strategies, such as periodically harvested areas common in Melanesia (Cohen and Foale 2013), can be incorporated in a zoning plan alongside zones that offer more strict protection for biodiversity features (Weeks and Jupiter 2013).

In Tun Mustapha Park, zoning was used not only to balance competing management objectives, but also to ensure equitable benefits for local communities: fishing grounds close to communities were prioritized for inclusion in zones that permit access to local fishers; recreational and commercial fishers were excluded from community-managed zones; and preservation zones were located close to community-managed zones, so that fishers might benefit from spillover.

5. Learning networks. Perhaps the biggest challenge for growing the CTMPAS will be replicating the small-scale successes documented here across the vast inshore marine area of the Coral Triangle. This task will be facilitated through widespread dissemination of lessons learned and best practices for MPA network design and implementation, in formats and venues that are accessible to MPA managers. The development of learning networks, apparent in our case studies, is therefore encouraging.

Nusa Penida MPA has been established as learning site, where prospective MPA managers can come to learn about MPA establishment processes. The Verde Island Passage is a member of the Philippine MPA Support Network and has also been identified as a U.S. Coral Triangle Initiative Integration and Learning Site. LMMA communities in Kimbe Bay are participating in the PNG Learning and Training Network. Similarly, the MPAs in neighbouring Choiseul Province are part of the Solomon Islands LMMA network, and LLCTC members have been sharing their experiences with the Council of Chiefs in Isabel Province. Finally, the model of co-management developed in Nino Konis Santana National Park has been 
documented to share with other sites in Timor-Leste. At the national level, learning and support networks such as the Solomon Islands Locally Managed Marine Areas network (SILMMA), Philippine MPA Support Network (MSN), and Papua New Guinea Centre for Locally Managed Areas (PNG CLMA), disseminate information, provide a venue for MPA managers to share experiences, and offer incentives for effective management (Campos and Alino 2008; Cohen et al. 2012).

\section{Conclusions}

The six case studies that we describe here represent small-scale successes in developing MPA networks appropriate to ecological, social and governance contexts of the Coral Triangle. In all cases, implementation is ongoing: MPA network designs, zoning plans, and management strategies will continue to evolve in response to new information and feedback on the effectiveness of applied actions. True success will be measured through effective implementation, resulting increase and/or maintenance of populations of priority marine species, and continued fisheries benefits to local communities. For this reason, it is premature to evaluate these MPA networks in terms of specific measures of ecological or social objectives. Nevertheless, these MPA networks demonstrate the promise of a region-wide CTMPAS, the sum of which will sustain marine and coastal ecosystems, and the populations that depend upon them, by improving the scientific basis and quality of management.

\section{References}

Allen, G. R. 2008. Reef Fish of Nusa Penida, Indonesia. Final report to Conservation International. Andrew, N., K. S. Pheng, and M. Philips. 2011. Fisheries Dependence in Timor-Leste: a Scoping Study. Coral Triangle Support Partnership.

Aswani, S., and R. J. Hamilton. 2004. Integrating indigenous ecological knowledge and customary sea tenure with marine and social science for conservation of Bumphead Parrotfish (Bolbometopon Muricatum) in the Roviana Lagoon, Solomon Islands. Environmental Conservation 31 (1): 69-83. doi:10.1017/S037689290400116X

Ban, N. C., V. M. Adams, G. R. Almany, S. Ban, J. E. Cinner, L. J. McCook, M. Mills, R. L. Pressey, and A. White. 2011. Designing, implementing and managing marine protected areas: Emerging trends and opportunities for coral reef nations. Journal of Experimental Marine Biology and Ecology 408 (1-2): 21-31. doi:10.1016/j.jembe.2011.07.023

Berkes, F. 2006. From community-based resource management to complex systems: The scale issue and marine commons. Ecology and Society 11 (1): 45-60.

Campos, W. L., and P. M. Alino. 2008. "Recent Advances in the Management of Marine Protected Areas in the Philippines." Kuroshio Science 2 (1): 29-34.

Campos, W. L., P. D. Belida II, M. P. Noblezada, and J. C. Asis. 2007. Investigating Biodiversity Corridors in the Sulu Sea: Distribution and Dispersal of Fish Larve. Iloilo, Philippines: University of the Philippines Visayas.

Carpenter, K. E., and V. G. Springer. 2005. The center of the center of marine shore fish biodiversity: The Philippine Islands. Environmental Biology of Fishes 72 (4): 467-480.

Christie, P., and A. T. White. 2007. Best practices for improved governance of coral reef marine protected areas. Coral Reefs 26 (4): 1047-1056. doi:10.1007/s00338-007-0235-9

Christie, P., R. B. Pollnac, E. G. Oracion, A. s Sabonsolin, R. Diaz, and D. Pietri. 2009. Back to basics: An empirical study demonstrating the importance of local-level dynamics for the success of tropical marine ecosystem-based management. Coastal Management 37 (3-4): 349-373. doi:10.1080/08920750902851740 
Cinner, J. E. 2007. Designing marine reserves to reflect local socioeconomic conditions: Lessons from long-enduring customary management systems. Coral Reefs 26 (4): 1035-1045. doi:10.1007/s00338-007-0213-2

Cinner, J. E., X. Basurto, P. Fidelman, J. Kuange, R. Lahari, and A. Mukminin. 2012. Institutional designs of customary fisheries management arrangements in Indonesia, Papua New Guinea, and Mexico. Marine Policy 36 (1): 278-285. doi:10.1016/j.marpol.2011.06.005

Cohen, P. J., and S. J. Foale. 2013. Sustaining small-scale fisheries with periodically harvested marine reserves. Marine Policy 37 (January): 278-287. doi:10.1016/j.marpol.2012.05.010

Cohen, P. J., L. S. Evans, and M. Mills. 2012. Social networks supporting governance of coastal ecosystems in Solomon Islands. Conservation Letters 5 (5): 376-386. doi:10.1111/j.1755263X.2012.00255.X

Conservation International Philippines. 2009. Scaling Up From MPAs to Seascapes: Lessons Learned From the Sulu-Sulawesi Seascape. Quezon City.

Conservation Plan for the Sulu-Sulawesi Marine Ecoregion. 2003. Conservation Plan for the SuluSulawesi Marine Ecoregion. Ed. Stakeholders of the SSME, Technical working groups of Indonesia Malaysia and the Philippines, WWF-SSME Conservation Program Team. Quezon City, Philippines: World Wide Fund for Nature.

Cruz-Trinidad, A. P., M., Aliño, R. C., Geronimo, and R. B. Cabral. 2014. Linking food security with coral reefs and fisheries in the Coral Triangle. Coastal Management 42: 160-182.

CTI-CFF. 2009. Coral Triangle Initiative on Coral Reefs, Fisheries and Food Security Regional Plan of Action. Jakarta, Indonesia: CTI-CFF. http://www.coraltriangleinitiative.org

Cumming, G. S., D. H. M. Cumming, and C. L Redman. 2006. Scale mismatches in social-ecological systems: Causes, consequences, and solutions. Ecology and Society 11 (1): 14.

Diamond, J. M. 1976. Species-area relation for birds of the Solomon Archipelago. Proceedings of the National Academy of Sciences 73:262-266.

EcoGov Project. 2011. Lessons From the Philippines: Achieving Synergies Through Marine Protected Area Networks Ed. P. M. Alino, P. M. Q. Cunanan, M. A. Juinio-Meñez, and R. R Paz. Pasig City, Philippines: Philippine Environmental Governance Project (EcoGov).

Edyvane, K., N. De Carvalho, S. Penny, S. Fernandes, C. B. Da Cunha, A. L. Amaral, and M. Mendes. 2009. Conservation Values, Issues and Planning in the Nino Konis Santana Marine Park, Timor-Leste. Dili, Timor-Leste: ATSEF-Ministry of Agriculture and Fisheries. Government of Timor-Leste.

Eisma-Osorio, R.-L., R.r C. Amolo, A. P. Maypa, A. T. White, and Patrick Christie. 2009. Scaling up local government initiatives toward ecosystem-based fisheries management in Southeast Cebu Island, Philippines. Coastal Management 37 (3-4): 291-307. doi:10.1080/08920750902851237

Fernandes, L., Jon Day, A. Lewis, S. Slegers, B. Kerrigan, D. Breen, D. Cameron, et al 2005. Establishing representative no-take areas in the Great Barrier Reef: Large-scale implementation of theory on marine protected areas. Conservation Biology: The Journal of the Society for Conservation Biology 19 (6): 1733-1744. doi:10.1111/j.1523-1739.2005.00302.x

Game, E. T., G. Lipsett-Moore, R. Hamilton, N.Peterson, J.Kereseka, W. Atu, M. Watts, and Hugh Possingham. 2011. Informed opportunism for conservation planning in the Solomon Islands. Conservation Letters 4 (1): 38-46. doi:10.1111/j.1755-263X.2010.00140.x

Grantham, H. S., V. N. Agostini, J. Wilson, S. Mangubhai, N. Hidayat, A. Muljadi, Muhajir, et al 2012. A comparison of zoning analyses to Inform the planning of a marine protected area network in Raja Ampat, Indonesia. Marine Policy (July 22): 1-11. doi:10.1016/j.marpol.2012.05. 035 (accessed September 2013).

Green, A., P. Lokani, W. Atu, P. Ramohia, P. Thomas, and J. Almany. 2006. Solomon Islands Marine Assessment: Technical Report of Survey Conducted May 13 to June 17, 2004. TNC Pacific Island Countries Report.

Green, A., S. E. Smith, G. Lipsett-Moore, C. Groves, N. Peterson, S. Sheppard, P. Lokani, et al. 2009. Designing a resilient network of marine protected areas for Kimbe Bay, Papua New Guinea. Oryx 43 (4): 488-498. doi:10.1017/S0030605309990342. 
Green, A. L. Fernandes, G. Almany, R. Abesamis, E. McLeod, P. Aliño, A. White, R. Salm, J. Tanzer, R. Pressey. 2014. Designing marine reserves for fisheries management, biodiversity conservation and climate change adaptation. Coastal Management 42:143-159.

Green, S. J., Al. T. White, P. Christie, S. Kilarski, A. T. Meneses, G. Samonte-Tan, L. B. Karrer, H. Fox, S. Campbell, and J. D. Claussen. 2011. Emerging marine protected area networks in the Coral Triangle: Lessons and way forward. Conservation and Society 9 (3): 173-188. doi:10.4103/0972-4923.86986

Halpern, B. S., C. J. Klein, and C. J. Brown. 2013. Achieving the triple bottom line in the face of inherent trade-offs among social equity, economic return, and conservation. PNAS 110 (15): 6229-6234. doi:10.1073/pnas.1217689110/-/DCSupplemental.

Hamilton, R. J., T. Potuku, and J. R. Montambault. 2011. Community-based conservation results in the recovery of reef fish spawning aggregations in the Coral Triangle. Biological Conservation 144 (6): 1850-1858. doi:10.1016/j.biocon.2011.03.024

Horigue, V., Porfirio M. Alino, Alan T. White, and Robert L. Pressey. 2012. Marine protected area networks in the Philippines: Trends and challenges for establishment and governance. Ocean \& Coastal Management 64 (August): 15-26. doi:10.1016/j.ocecoaman.2012.04.012

Klein, C. J., C. Steinback, A. J. Scholz, and H. P. Possingham. 2008. Effectiveness of marine reserve networks in representing biodiversity and minimizing impact to fishermen: A comparison of two approaches used in California. Conservation Letters 1 (1): 44-51. doi:10.1111/j.1755.263X.2008.00005.x

Klein, C. J., C. Steinback, M. Watts, A. J. Scholz, and H. P. Possingham. 2010. Spatial marine zoning for fisheries and conservation. Frontiers in Ecology and the Environment 8 (7): 349-353. doi: $10.1890 / 090047$

Koczberski, G., G. N. Curry, and J. Warku. 2006. Village-Based Marine Resource Use and Rural Livelihoods: Kimbe Bay, West New Britain, Papua New Guinea. TNC Pacific Island Countries Report.

Lee, Y. L., and R. Jumin. 2007. Establishing Sociological and Ecological Criteria for Zoning in the Proposed Tun Mustapha Park. WWF Malaysia.

Lipsett-Moore, G., R. J. Hamilton, N. Peterson, E. T. Game, W. Atu, J. Kereseka, J. Pita, and P. Ramohia. 2010. Ridges to Reefs Conservation Plan for Choiseul Province, Solomon Islands. TNC Pacific Island Countries Report.

McCook, L. J., G. R. Almany, M. L. Berumen, J. C. Day, A. L. Green, G. P. Jones, J. M. Leis, et al. 2009. Management under uncertainty: Guide-lines for incorporating connectivity into the protection of coral reefs. Coral Reefs 28 (2): 353-366. doi:10.1007/s00338-008-0463-7

McLeod, E., R. Salm, A. Green, and J. Almany. 2009. Designing marine protected area networks to address the impacts of climate change. Frontiers in Ecology and the Environment 7 (7): 362-370. doi:10.1890/070211

Melbourne-Thomas, J., C. R. Johnson, P. M. Alino, Rollan C. Geronimo, C. L. Villanoy, and G. G. Gurney. 2011. A multi-scale biophysical model to inform regional management of coral reefs in the Western Philippines and South China Sea. Environmental Modelling and Software 26 (1): $66-82$.

Mills, M., R. L. Pressey, R. Weeks, S. Foale, and N. C. Ban. 2010. A mismatch of scales: Challenges in planning for implementation of marine protected areas in the Coral Triangle. Conservation Letters 3 (5): 291-303. doi:10.1111/j.1755-263X.2010.00134.x

Morrison, C., P. Pickacha, and T. Pitakia. 2007. Herpetofauna, community education and logging on Choiseul Island, Solomon Islands: Implications for conservation. Pacific Conservation Biology 13:250-258.

Ong, P. S., L. E. Afuang, and R. G. Roselle-Ambal, eds. 2000. Philippine Biodiversity Conservation Priorities: a Second Iteration of the National Biodiversity Strategy and Action Plan. Quezon City, Philippines: Department of Environment and Natural Resources -Protected Areas and Wildlife Bureau, Conservation International Philippines, Biodiversity Conservation Program University of the Philippines Center for Integrative and Development Studies and Foundation for the Philippine Environment. 
Planes, S., G. P. Jones, and S. R. Thorrold. 2009. Larval dispersal connects fish populations in a network of marine protected areas. Proceedings of the National Academy of Sciences of the United States of America 106 (14): 5693-5697.

Quibilan, M. C., P. M. Alino, S. Vergara, and R. B. Trono. 2008. Establishing MPA networks in marine biodiversity conservation corridors. Tropical Coasts 15 (1): 38-45.

Russ, G. R., and A. C. Alcala. 1999. Management histories of Sumilon and Apo Marine Reserves, Philippines, and their influence on national marine resource policy. Coral Reefs 18 (4): 307-319.

Teh, L., A. S. Cabanban, and U. Rashid Sumaila. 2005. The reef fisheries of Pulau Banggi, Sabah: A preliminary profile and assessment of ecological and socio-economic sustainability. Fisheries Research 76 (3): 359-367. doi:10.1016/j.fishres.2005.07.009

Turak, E., and L. De Vantier. 2009. Biodiversity and Conservation Priorities of Reef-Building Corals in Nusa Penida. Final report to Conservation International.

Vergara, S., R. M. P. Rosales, M. C. Quibilan, H. Ibuna, H. Froyalde, R. Villanueva, and W. Azucena. 2008. Partnerships at work in the Seas of Sulu and Sulawesi. Tropical Coasts 15 (1): 12-21.

Villanoy, C. L., M. Magno-Canto, and O. Cabrera. 2007. Investigating Biodiversity Corridors in the Sulu Sea: Oceanography Component. Quezon City, Philippines: University of the Philippines, Diliman.

Watts, M. E., I. R. Ball, R. S. Stewart, C. J. Klein, K. Wilson, C. Steinback, R. Lourival, L. Kircher, and H. P. Possingham. 2009. Marxan with zones: Software for optimal conservation based land- and sea-use zoning. Environmental Modelling and Software (July 21): 1-9. doi:10.1016/j.envsoft.2009.06.005

Weeks, R., and S. Jupiter. 2013. Adaptive comanagement of a marine protected area network in Fiji. Conservation Biology 27:1234-1244.

Weeks, R., G. R. Russ, A. A. Bucol, and A. C. Alcala. 2010a. Incorporating local tenure in the systematic design of marine protected area networks. Conservation Letters 3 (6): 445-453. doi:10.1111/j.1755-263X.2010.00131.x

Weeks, R., G. R. Russ, A. C. Alcala, and A. T. White. 2010b. Effectiveness of marine protected areas in the Philippines for biodiversity conservation. Conservation Biology 24 (2): 531-540. doi:10.1111/j.1523-1739.2009.01340.x

White, A. T., A. B. T. Meneses, M. Ovenden, and S. Tesch. 2006. Sustaining marine protected areas through continued monitoring and evaluation: The MPA Report Guide and Management Rating System. Proceedings of 10th International Coral Reef Symposium, 1466-1470 (July 24): 1-5.

White, A. T., C. A. Courtney, and A. Salamanca. 2002. Experience with marine protected area planning and management in the Philippines. Coastal Management 30 (1): 1-26.

White, A., P. Aliño, A. Cros, N. Ahmad Fatan, A. Green, S. J. Teoh, L. Laroya, et al. 2014. Marine protected areas in the Coral Triangle: Progress, issues and options. Coastal Management 42: $87-106$. 